\title{
Dinoflagellate biostratigraphy of Eastern Indonesia stratigraphy: key of petroleum exploration success
}

\section{Herman Darman}

Indogeo Social Enterprise, currently with Petronas, Kuala Lumpur, Malaysia

\begin{abstract}
Several major discoveries in the eastern part of Indonesia (e.g. Tangguh and Abadi) have increased more petroleum exploration interest in the area. These sizeable discoveries encountered gas in the Jurassic sandstone, which is a key reservoir target in the Northwest Shelf of Australia. The Mesozoic sandstone provenance is located in the Australian Continental Plate or also known as the Sahul Shelf. Thousands of wells were drilled in the Sahul Shelf and the stratigraphy in this area is well understood. The extension of the Mesozoic sandstone towards Indonesian territory, with much less well information, is one of the keys of success for petroleum exploration. Refinement of the stratigraphy of the eastern part of Indonesia is crucial to understand the extension.
\end{abstract}

To refine the stratigraphy of Eastern Indonesia, especially for the Mesozoic interval, dinoflagellates play a significant role. Several types of this marine biota have been used by Australian stratigraphers as markers. In the case where stratigraphic tie to Northwest Shelf Australia discoveries, key wells or standard chronostratigraphy, dinoflagellate understanding is critical.

\section{Copyright (C2021. FOSI. All rights reserved.}

A Special Publication of abstracts and extended abstracts from the conference in honor of the retirement of Prof. Yahdi Zaim, IPU (22-23 March 2021). 
Dinoflagellate markers are used to mark several subdivisions of Plover Sandstone. Norvick (2001) used W. indotata and D. caddaensis Maximum Flooding Surfaces to subdivide the reservoir target into upper, middle and lower Plover Formation. These surfaces are named after dinoflagellates. More markers were identified to mark the source rock and seal in the petroleum system. To have a detail correlation from Indonesia to the NW Shelf, understanding of dinoflagellates is crucial.

Keywords: dinoflagellate, eastern Indonesia, Australia Northwest Shelf, Sahul Shelf 